\title{
Ovum morphology after hyperthermic stress during meiotic maturation and ovulation in the mouse
}

\author{
A. P. Baumgartner and C. L. Chrisman \\ Cytogenetics Laboratory, Department of Animal Sciences, Purdue University, \\ West Lafayette, Indiana 47907, U.S.A.
}

\begin{abstract}
Summary. Eggs were collected from 60 virgin ICR mice $15 \frac{1}{2} \mathrm{~h}$ after synchronization of ovulation with PMSG and hCG from control females and those exposed for $15 \frac{1}{2} \mathrm{~h}$ to hyperthermic conditions $\left(35 \pm 1^{\circ} \mathrm{C}, 65 \pm 3 \%\right.$ relative humidity) immediately after the hCG injection. Eggs were classified for analysis as monocellular, bicellular, tricellular equal, tricellular unequal, multicellular and degenerate. Egg class frequencies were affected by increasing atypical forms $(P<0.01)$. Stressed animals had significantly larger cells when an analysis of variance was performed on the bicellular classification, but there was no effect on ovum diameter.
\end{abstract}

\section{Introduction}

The effects of adverse environmental conditions on reproduction of domestic and laboratory animals are of obvious economic and scientific importance. High ambient temperature alone or in combination with high humidity has wide ranging effects on parental fertility and the embryos they may produce (Ulberg, 1958; Hafez, 1964; Edwards, 1974). Possibly of greatest concern are the effects on gametogenesis, syngamy and embryogenesis, and their causative role in embryonic mortality and congenital defects (Dutt, 1963; Burfening, Elliott, Eisen \& Ulberg, 1970; Bellvé, 1972, 1973; Ulberg \& Sheean, 1973; Wildt, Riegle \& Dukelow, 1975; Pucak, Lee \& Zaind, 1977).

The effects of hyperthermic stress on unfertilized eggs have been studied by several investigators. Triturus eggs have been found to produce consistently 2 female pronuclei when subjected to heat shock treatment (Frankhauser \& Godwin, 1948). Braden \& Austin (1954), after exposing mouse tubal ova to high temperatures $\left(44-45^{\circ} \mathrm{C}\right), 8-12 \mathrm{~h}$ after ovulation found a high percentage of degeneration and a high percentage of eggs which appeared to have reformed nuclei resembling pronuclei. This exposure also caused a small percentage to cleave spontaneously, resembling parthenogenetic activation. Komar (1973) and Balhkier \& Tarkowski (1976) observed parthenogenetic development of mouse eggs after heat treatment.

Fischberg \& Beatty (1952) found that mouse eggs subjected to high temperatures around the time of fertilization yielded a high incidence of triploid embryos at $3 \frac{1}{2}$ days. Heat shock treatment of tubal ova with subsequent fertilization (Braden \& Austin, 1954) produced an increase in second polar body retention with a resultant increase in ploidy levels.

Although these studies have yielded some insight into the effects of high temperatures on unfertilized eggs, they have been limited to direct effects on the ova by rather extreme conditions. There is a lack of information on the morphology and cytology of ova exposed to moderate levels of hyperthermia during meiotic maturation and ovulation. The present study was undertaken to determine some of those effects at a level of hyperthermic stress compatible with maternal and at least partial ovum survival. 


\section{Materials and Methods}

Sixty (60) random-bred virgin female ICR mice, 12-16 weeks of age, were obtained from a single generation with 2 control and 3 animals to be heat stressed allotted to each of 12 replicates from the experiment. Doses of 3 i.u. PMSG (Parlow, Torrence, California) followed $48 \mathrm{~h}$ later by 3 i.u. hCG (Ayerst Laboratories, New York) were given to produce synchronous ovulation. The PMSG and hCG were reconstituted to $15 \mathrm{i} . \mathrm{u} . / \mathrm{ml}$ in $0.85 \%(\mathrm{w} / \mathrm{v}$ ) $\mathrm{NaCl}$ solution, and injected intraperitoneally. Immediately following injection of hCG the mice were exposed to either $21 \pm 2^{\circ} \mathrm{C}$ and $65 \pm 5 \%$ relative humidity $(\mathrm{RH})$ or $35 \pm 1^{\circ} \mathrm{C}$ and 65 $\pm 3 \% \mathrm{RH}$. After $15 \frac{1}{2} \mathrm{~h}$ the animals were removed from the environmental chambers and killed by cervical dislocation. The reproductive tracts were removed and then examined at $\times 20$ with a dissecting microscope and the numbers of ovulation sites on each side were recorded. The cumulus mass was liberated from each oviduct and transferred to a $0 \cdot 1 \%(\mathrm{w} / \mathrm{v})$ solution of hyaluronidase (No. H 2001: Sigma Chemical Co., St. Louis, Missouri) in Hanks' balanced salt solution (HBSS) adjusted to $\mathrm{pH}$ 7.2. All subsequent manipulations were performed with a fine-drawn mouth-controlled pipette. Each cumulus mass was exposed to the hyaluronidase solution for $10 \mathrm{~min}$ at $37^{\circ} \mathrm{C}$ and then mechanically broken up if still intact. Ova from each mass were collected and counted for comparison with the number of observed ovulation sites. After another $5 \mathrm{~min}$ in the hyaluronidase solution to remove any remaining coronal cells, the ova were pooled and immediately transferred to a solution of $50 \%$ in activated fetal bovine serum in HBSS. After inactivation of the hyaluronidase $(5-10 \mathrm{~min})$ the ova were transferred to a fresh solution of neutral red stock $(1: 9 \mathrm{v} / \mathrm{v})$ with filtered $20 \%$ inactive fetal bovine serum in HBSS for $5 \mathrm{~min}$.

Observations included ovum measurements and classification of eggs into 6 categories (see below). Measurements were made at $\times 100$ with an eyepiece micrometer calibrated with a stage micrometer. Photographs of representative eggs were taken at $\times 160$ and $\times 200$.

Analyses of variance were performed on mean ovum diameter, variance of ovum diameter, mean cell diameter and variance of cell diameter of eggs classified bicellular, and on the egg class proportions transformed to angles.

\section{Egg classification}

Monocellular. These were ova having only one cell and not showing signs of degeneration (Pl. 1, Fig. 1).

Bicellular. These were eggs containing 2 cells, one presumed to be the first polar body. Eggs with a large first polar body, a subclass of bicellular, were identified as eggs with a single polar body equal to or greater than $33 \%$ of the ovum diameter ( $\mathrm{Pl}$. 1, Figs 1 and 2 ).

Tricellular equal. These eggs contained 3 cells, the smaller of which were equal in diameter.

Tricellular unequal. These were eggs containing 3 cells of unequal diameter (Pl. 1, Fig. 3).

Multicellular. These eggs contained more than 3 cells (Pl. 1, Figs 4, 5 and 6).

Degenerate. These were eggs showing one or more of the following characteristics: large non-staining areas; usually one, but sometimes several darkly staining tight aggregates of cellular organelles near the periphery of the oocyte with little or no staining in other areas; lysis into the perivitelline space; or highly irregular shape, primarily characterized by protrusions of ovum cytoplasm lacking organelles (PI. 2, Figs 7, 8 and 9).

\section{Results}

During this study it was observed that the cumulus masses of heat-stressed females tended to break down and release their oocytes in a shorter time than did those of control females. This resulted in prolonged exposure of the ova to digestion in the hyaluronidase solution. Also, the zonae pellucidae of some eggs from heat-stressed females disrupted more quickly than did those of controls, thereby requiring closer observation and sometimes shorter exposure times than for 

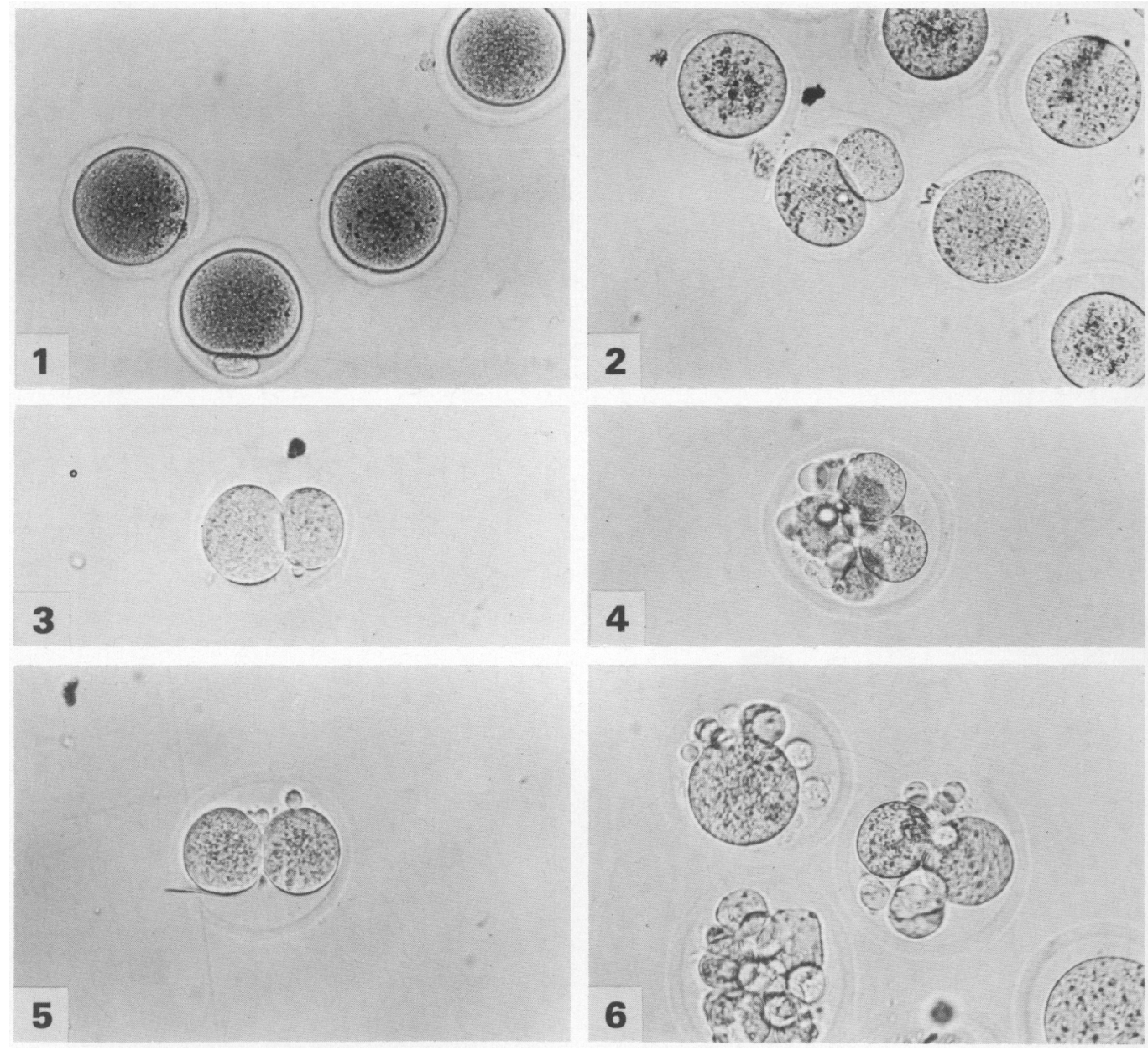

Fig. 1. Typical eggs of the monocellular and bicellular classifications from a heat-stressed female. $\times 160$.

Fig. 2. Oocyte of the bicellular, large first polar body, class. $\times 160$.

Fig. 3. Oocyte of the tricellular unequal class, possibly representing a spontaneously cleaved secondary oocyte with persisting polar body. $\times 160$.

Figs 4-6. Multicellular oocytes indicating some of the many forms observed. $\times 200$. 

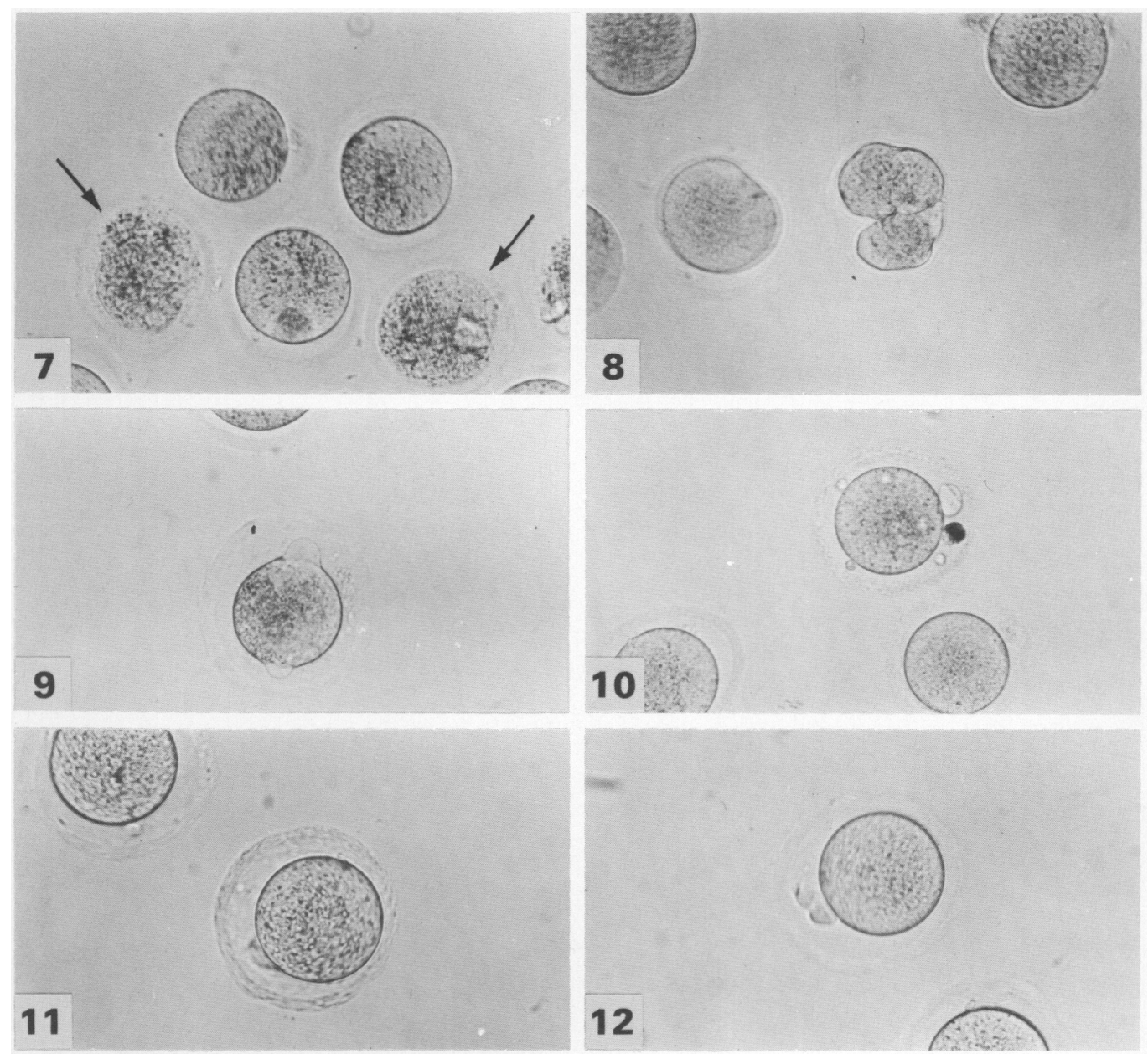

Fig. 7. A group of oocytes containing degenerate forms (arrows). $\times 160$.

Fig. 8. An irregular oocyte of the degenerate class. $\times 160$.

Fig. 9. An egg exhibiting protrusions of the cytoplasm. $\times 160$.

Figs 10 and 11. Eggs exhibiting zonae pellucidae with a granular appearance. Fig. 10, $\times 160$; Fig. $11, \times 200$.

Fig. 12. Oocyte with polar body in mid-division. $\times 200$. 
controls. This tendency, however, was not quantified. Furthermore, the zonae pellucidae of eggs from several heat-stressed animals appeared granular (see Pl. 2, Figs 9-11).

A strong association between observed numbers of ovulation sites (859), eggs recovered (899), and actual number of eggs processed (888) indicates the usefulness of this procedure for the study of ovulated ova. Analysis of mean ovum diameter and variance of ovum diameter did not show any significant effects of hyperthermia on this measurement. However, the mean cell diameter of eggs of the bicellular classification within the heat-stressed group proved to be significantly different $(P<0.01)$ from that of controls: 59 control eggs had a mean cell diameter of $11.29 \pm 3.94 \mu \mathrm{m}$ compared to $18.09 \pm 3.70 \mu \mathrm{m}$ for 183 eggs from heat-stressed females. Analysis of the variance of cell diameter (control, $S^{2}=15.55$; heat-stressed, $S^{2}=13.67$ ) showed a significant difference between treatments (see Table 1).

Table 1. Summary of egg recovery and measurement data

\begin{tabular}{|c|c|c|c|c|c|c|c|c|}
\hline \multirow[b]{2}{*}{ Treatment } & \multirow{2}{*}{$\begin{array}{l}\text { No. of } \\
\text { females }\end{array}$} & \multirow{2}{*}{$\begin{array}{c}\text { No. of } \\
\text { ovulation } \\
\text { sites } \\
\text { (no./female) }\end{array}$} & \multirow{2}{*}{$\begin{array}{l}\text { No. of eggs } \\
\text { recovered } \\
\text { (no./female) }\end{array}$} & \multirow{2}{*}{$\begin{array}{l}\text { No. of eggs } \\
\text { processed }\end{array}$} & \multicolumn{2}{|c|}{$\begin{array}{c}\text { Ovum } \\
\text { diam. }(\mu \mathrm{m})\end{array}$} & \multicolumn{2}{|c|}{$\begin{array}{c}\text { Cell } \\
\text { diam. }(\mu \mathrm{m})\end{array}$} \\
\hline & & & & & Mean & s.d. & Mean & s.d. \\
\hline Control & 24 & $\begin{array}{c}359 \\
(14 \cdot 1)\end{array}$ & $\begin{array}{c}390^{\dagger} \\
(16)\end{array}$ & $384 \dagger$ & $79 \cdot 34$ & $2 \cdot 06$ & $11 \cdot 29$ & 3.94 \\
\hline Heat & 36 & $\begin{array}{c}500 \\
(13.9)\end{array}$ & $\begin{array}{c}509 \\
(14 \cdot 1)\end{array}$ & 504 & 78.83 & $4 \cdot 15$ & $18.09^{*}$ & $3 \cdot 70$ \\
\hline
\end{tabular}

* Significantly different from control value $(P<0.01)$.

$\dagger$ Includes 2 fragmenting and 17 degenerating eggs from 3 females (see text).

An arc-sine transformation was performed on egg class frequencies which were then analysed using Treatment and Classification as main effects. Before analysis the data were corrected using the Bartlett correction factors of $\frac{1}{4} n$ and $1-\frac{1}{4} n$ for proportions of 1 and $100 \%$, respectively. The analysis of variance showed that the frequencies of the monocellular, bicellular and tricellular equal classes had been significantly altered by heat treatment (Table 2). Although the other values were also increased, they were not significantly different because of the great variation between females.

Table 2. Egg class frequency and Newman-Keuls Range Test data

\begin{tabular}{lcc}
\hline \multicolumn{1}{c}{ Egg class } & $\begin{array}{c}\text { Control } \\
(\mathrm{N}=24)\end{array}$ & $\begin{array}{c}\text { Heat-stressed } \\
(\mathrm{N}=36)\end{array}$ \\
\hline Monocellular & $291(75.8 \%)$ & $177(35 \cdot 1 \%)^{*}$ \\
Bicellular & $59(15.4 \%)$ & $152(30 \cdot 2 \%)^{*}$ \\
Large polar body $\dagger$ & $0(0.0 \%)$ & $31(6 \cdot 1 \%)$ \\
Tricellular equal & $5(1.3 \%)$ & $42(8.3 \%)^{*}$ \\
Tricellular unequal & $0(0.0 \%)$ & $16(3.2 \%)$ \\
Multicellular & $2(0.5 \%) \ddagger$ & $25(5.0 \%)$ \\
Degenerate & $27(7.0 \%) \S$ & $61(12.1 \%)$ \\
Total & 384 & 504 \\
\hline
\end{tabular}

* These percentages are significantly different from control values $(P<0.01)$.

$\dagger$ Eggs with a polar body diameter $\geq 33 \%$ of the ovum diameter.

$\ddagger$ Found peripheral to the cumulus mass.

$\$$ Includes 17 eggs (from 3 females) found peripheral to the cumulus mass. 


\section{Discussion}

Studies involving maternal heat stress have been largely conducted at or around the time of fertilization and at various stages of cleavage and embryo development. Studies involving tubal eggs have been conducted on older eggs and at temperatures which, in most cases, were in excess of the limit compatible with maternal survival over extended periods. In these studies, and those on fertilization, it is also difficult to remove the direct and residual effects of the increased temperature on the spermatozoa. There is little knowledge about the effects of mild stress compatible with maternal survival, as was used in the present experiment. This stress more closely approximates what might be seen in geographic areas of widely fluctuating temperatures.

From previous studies conducted in our laboratory, the hyperthermic stress imposed on ICR mice yields an average $1^{\circ} \mathrm{C}$ rise in body temperature. The results of this experiment indicate that this stress during meiotic maturation yields increased atypical and degenerate ova. The multicellular or fragmented eggs and degenerate forms found resemble those seen in both ageing and activated tubal eggs (Szollosi, 1971; Graham, 1974). However, such forms are seen in ageing eggs between 16 and $24 \mathrm{~h}$ after ovulation (Szollosi, 1971; A. P. Baumgartner, unpublished), as compared to $2-4 \mathrm{~h}$ after ovulation in this study. Tubal eggs have been activated by heat, chemical and electrical stimuli $8-12 \frac{1}{2} \mathrm{~h}$ after ovulation. However, the results of our study may be related to the ageing process. The possibility exists that heat stress in conjunction with hCG injection initiates maturation and/or ovulation earlier than the assumed schedule (Kuhlman, 1970), and so the eggs of the experimental females would be older than expected. This was not investigated, although it might explain the observations on the cumulus masses and advanced fragmentation of some oocytes.

Increased size of the first polar body in the stressed animals was most probably due to displacement of the entire spindle apparatus towards the centre of the ovum before cytokinesis. This phenomenon has been observed in both ageing and activated eggs (Donahue, 1970; Szollosi, 1973). Large first polar bodies are seen only rarely (frequency of $0.04-0.4 \%$ ) in normal ovulated ova (Donahue, 1973). In this study none was observed in control eggs as compared to a frequency of $6 \cdot 1 \%$ in stressed animals. The significantly larger size of first polar bodies in the heat-stressed animals may also yield insight into the increased number of eggs with an intact polar body at the time of observation. It is generally believed that the first polar body degenerates before or soon after ovulation (Donahue, 1968). Large polar bodies having a greater share of the ovum cytoplasm than a normal first polar body are therefore more like a normal secondary ovum and possibly as competent with respect to survival and fertilization. Zamboni (1971) observed that large non-degenerate first polar bodies contained metaphase II spindles. Fertilization of both the ovum and the first polar body leading to mosaicism in the embryo is a rare event but seems much more probable if the first polar body is large. Several of the eggs with a large first polar body appeared similar to the spontaneously cleaved ova described by Braden (1957).

Several possible explanations exist for the tricellular equal classification. Increased numbers of eggs with 2 cells of equal diameter may also be explained by more equal first maturation division with subsequent division of the polar body. In the normal first polar body the chromosomes remain in chromatid pairs and retain their rather close compact association. Spindle mechanisms and post-metaphase stages have been observed previously in polar bodies of ova (Odor, 1955; Austin, 1961). However, the assumed division of the polar bodies was only once seen (see Pl. 2, Fig. 12). The ovum chromatin may also be extruded into 2 equal cells (Donahue, 1970). This anomaly is, however, much more frequent at the second meiotic division where it may occur at a frequency of $0 \cdot 1 \%$ (Donahue, 1973).

Tricellular eggs with unequal cell diameters might also arise as explained above or may be due to fragmentation of the larger first polar body or the start of fragmentation of the egg. 
Several eggs with the larger cells more equal in diameter than the smaller cells may be similar to spontaneous cleavage with persistence of the first polar body (see Pl. 1, Fig. 3).

Eggs of the multicellular or fragmenting group are clearly degenerate, and there was a high incidence even at such a short time (2-4 h) after ovulation. An experiment involving whole mounted eggs stained to locate chromatin would be useful in determining the exact nature of the tricellular and multicellular eggs. The disparity between the control and experimental groups would have been greater, but 17 degenerate eggs were found in 3 control females. These eggs were found peripheral to the cumulus mass and were assumed to be from ovulations in response to the PMSG injection. Eggs ovulated in response to the PMSG remained normal in appearance for 20-32 $\mathrm{h}$ and then degenerated before the hCG-induced ovulations, as observed by Neal \& Baker (1973). Most of these eggs in the present study were in an advanced stage of degeneration, characterized by a condensed mass of debris peripherally located in an irregularly shaped zona pellucida. Eggs peripheral to the cumulus mass were not seen in heat-stressed animals and it can only be assumed that increased temperature caused an advance in ageing of any eggs present. Further studies to determine the cytogenetic effects of this treatment regimen and the subsequent fertility of these oocytes are being conducted.

We thank Dr B. B. Bohren for help with the experimental design and statistical analyses. Journal Paper No. 7853 of the Purdue Agricultural Experiment Station.

\section{References}

Austin, C.R. (1961) The Mammalian Egg. Blackwell, Oxford.

Balhkier, H. \& Tarkowski, N.J. (1976) Diploid parthenogenetic mouse embryos produced by heat shock and cytochalasin B. J. Embryol. exp. Morph. 35, 25-39.

Bellvé, A.R. (1972) Viability and survival of mouse embryos following parental exposure to high temperature. J. Reprod. Fert. 30, 71-81.

Bellvé, A.R. (1973) Development of mouse embryos with. abnormalities induced by parental heat stress. $J$. Reprod. Fert. 35, 393-403.

Braden, A.W.H. (1957) Variation between strains in the incidence of various abnormalities of egg maturation and fertilization in the mouse. J. Genet. 55, 476-486.

Braden, A.W.H. \& Austin, C.R. (1954) Reactions of unfertilized mouse eggs to some experimental stimuli. Expl Cell Res. 7, 277-280.

Burfening, P.J., Elliott, D.S., Eisen, E.J. \& Ulberg, L.C. (1970) Survival of embryos resulting from spermatozoa produced by mice exposed to elevated ambient tempe tur ' ${ }^{\circ}$ 1nim. Sci. 30, 578-582.

Donahue, R.P. ( $\left.{ }^{1}\right) 68$ ) Maturation of the mouse oocyte in vitro. I. Sequence and timing of nuclear progression. J. exp. Zool. 169, 237-250.

Donahue, R.P. (1970) Maturation of the mouse oocyte in vitro. II. Anomalies of the first polar body formation. Cytogenetics 9, 106-115.

Donahue, R.P. (1973) Normal and abnormal chromosome behavior in the meiotic division of mammalian oocytes. In Aging Gametes: their Biology and Pathology, pp. 50-71. Ed. R. J. Blandau. S. Karger, New York.

Dutt, R.H. (1963) Critical period for early embryo mortality in ewes exposed to high ambient temperature. J. Anim. Sci. 22, 713-719.

Edwards, M.J. (1974) The effects of hyperthermia on pregnancy and prenatal development. In Experimental Embryology and Teratology, pp. 90-133. Eds D. H. M. Woollam \& G. M. Morriss. Elek Science, London.

Fischberg, M. \& Beatty, R.A. (1952) Heteroploidy in mammals. II. Induction of triploidy in preimplantation mouse eggs. J. Genet. 50, 455-470.

Frankhauser, B. \& Godwin, D. (1948) The cytological mechanisms of the triploidy-inducing effect of heat on eggs of the newt, Triturus viridiscens. Proc. natn. Acad. Sci. U.S.A. 34, 544-551.

Graham, C.F. (1974) The production of parthenogenetic mammalian embryos and their use in biological research. Biol. Rev. 49, 399-422.

Hafez, E.S.E. (1964) Effects of high temperature on reproduction. Int. J. Biometer. 7, 223-230.

Komar, A. (1973) Parthenogenetic development of mouse eggs activated by heat shock. J. Reprod. Fert. 35, 433-443.

Kuhlman, W. (1970) Cytology and timing of meiotic stages in female germ cells of mammals and man. In Chemical Mutagenesis in Mammals and Man, pp. 180-193. Eds F. Vogel \& G. Rohrborn. SpringerVerlag, New York.

Neal, P. \& Baker, T.G. (1973) Response of mouse ovaries in vivo and in organ culture to Pregnant Mares Serum Gonadotrophin and Human Chorionic Gonadotrophin. I. Examination of critical time intervals. J. Reprod. Fert. 33, 399-410.

Odor, D.L. (1955) The temporal relationship of the first maturation division of rat ova to the onset of heat. Am.J. Anat. 97, 461-492.

Pucak, G.J., Lee, C.S. \& Zaind, A.S. (1977) Effects of prolonged high temperature on testicular development and fertility in the male rat. Lab. Anim. Sci. 27, $76-77$. 
Szollosi, D. (1971) Morphological changes in mouse eggs due to aging in the fallopian tube. Am. J. Anat. 130, 209-226.

Szollosi, D. (1973) Mammalian eggs aging in the fallopian tubes. In Aging Gametes: their Biology and Pathology, pp. 98-121. Ed. R. J. Blandau. S. Karger, New York.

Ulberg, L.C. (1958) The influence of high temperature on reproduction. J. Hered. 49, 62-64.
Ulberg, L.C. Sheean, L.A. (1973) Early development of mammalian embryos in elevated ambient temperatures. J. Reprod. Fert., Suppl. 19, 155-161.

Wild, D.E, Riegle, G.D. \& Dukelow, W.R. (1975) Physiological temperature response and embryonic mortality in stressed swine. Am. J, Physiol. 229, 1471-1475.

Zamboni, L.M. (1971) Fine Morphology of Mammalian Fertilization. Harper and Row, New York.

Received 25 March 1980 